\title{
Undeclared baggage: Do tourists act as vectors for seed dispersal in fynbos protected areas?
}

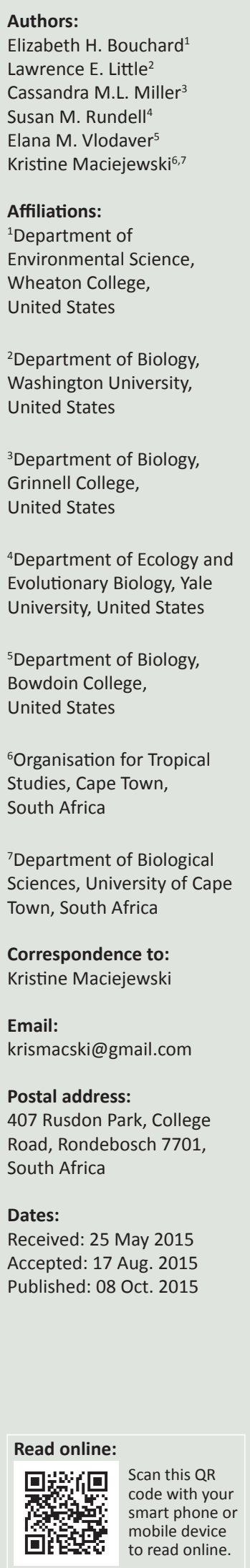

Encroachment by alien species is the second greatest threat to biodiversity worldwide. As South Africa's Cape Floristic Region has a botanical endemism of nearly 70\%, conservation efforts are a high priority. Estimates suggest that alien species cost the country over R6.5 billion per year. Despite significant research on alien species dispersal, the role of tourists as seed dispersers requires further exploration. To investigate the potential role tourists play in introducing alien seeds into protected areas, long-bristle brushes were used to scrape seeds off the shoes of hikers, dog walkers and cyclists, as well as the wheels of mountain bikes and dogs themselves, upon entering the Silvermine Nature Reserve section of the Table Mountain National Park in the Western Cape province, South Africa. In addition, a vegetation survey was conducted. This comprised 18 transects at various distances from the recreational paths in the park, and used a prioritisation ranking system that identified the alien species of greatest concern. It was concluded that the greatest number of alien plant species could be found along dog paths, in comparison to the hiking trails and cycling trails. This corresponded to the findings that dog walkers had the highest incidence of seeds on their shoes, suggesting that tourists were possibly dispersing seeds from their gardens. Alien species significantly covered more of the vegetation transects closer to the trails than they did in transects further into the matrix. Because more alien species were present in areas susceptible to human disturbance, the data suggest that tourists can act as vectors for alien seed dispersal. These findings emphasise the need for active tourism management in line with the South African National Parks Biodiversity Monitoring Programme in order to prevent the introduction and spread of alien species into South Africa's protected areas.

Conservation implications: Tourism is the main source of revenue for South African National Parks, and one of the organisation's principal goals is to create a tourism management policy conducive to conservation. This research explores the potential role that tourists may play in the introduction of non-native species into a protected area, thereby providing novel information that could assist managers in the sustainable management of protected areas.

\section{Introduction}

South Africa's Cape Floristic Region is a world-renowned hotspot for botanical biodiversity, home to some 9000 plant species, 70\% of which are endemic (Forest et al. 2007). However, alien species - the second greatest threat to biodiversity worldwide (Richardson \& Van Wilgen 2004) jeopardise the long-term survival of this region's staggering diversity.

An alien species can be defined as a non-native species, the introduction of which has the potential to cause health-related, economic or environmental damage (Swearingen et al. 2010). In South Africa alone, nearly 200 plant taxa are legally recognised as 'alien' (Wilson et al. 2013). These species degrade ecosystems through the excessive consumption of resources, the alteration of fire regimes, and the disruption of soil stability and composition (Richardson \& Van Wilgen 2004). Alien species cost South Africa an average of R6.5 billion per year, a sum set to grow by an order of magnitude in the near future (Wilson et al. 2013). The management of alien species is, therefore, vital to the biological and economic well-being of the country (Wilson et al. 2013).

Given that South Africa is home to 3 of the world's 25 biodiversity hotspots, managing alien species presents a particularly daunting task due to the already established vulnerability of these areas (Myers et al. 2000). South Africa has one of the worst problems with alien flora of any country in the world, and managers have never successfully eradicated an alien plant species nationwide (Richardson \& Van Wilgen 2004; Wilson et al. 2013).

How to cite this article: Bouchard, E.H., Little, L.E., Miller, C.M.L., Rundell, S.M., Vlodaver, E.M. \& Maciejewski, K., 2015, 'Undeclared baggage: Do tourists act as vectors for seed dispersal in fynbos protected areas?', Koedoe 57(1), Art. \#1323, 9 pages. http://dx.doi. org/10.4102/koedoe.v57i1.1323

Copyright: @ 2015. The Authors. Licensee: AOSIS OpenJournals. This work is licensed under the Creative Commons Attribution License. 
One of the challenges of containment and eradication is that, while managers may successfully clear above-ground individuals from a plot, the alien seed bank can persist in the soil for many decades, encouraging reinvasion (Wilson et al. 2011). Accordingly, a more effective management strategy is the prevention of seed dispersal (Wilson et al. 2011).

The introduction of any new alien species into a protected area is against the mandate of South African National Parks (SANParks), even when the potential for a particular species to become invasive is unknown (Foxcroft 2009). As such, one of the key functions of the SANParks Biodiversity Management Programme for Invasive Alien Species is the monitoring of potential introduction pathways (McGeoch et al. 2011). Research on such pathways has expanded from such vectors such as animal transport and wind to include the role of tourists (Pickering et al. 2011).

Tourists are often cited as playing a role in the dispersal of seeds through activities such as hiking and mountain biking. However, there is only a small body of evidence to support these claims. To date, only a single study on seed dispersal by tourists has been conducted in the entire continent of Africa (Pickering \& Mount 2010).

Circumstantial evidence suggests that alien species are found most commonly near paths in protected areas, and a correlation exists that links an increased visitor presence to a greater number of alien species in protected areas in Southern Africa (Usher 1988). This emerging field has no standardised techniques for collecting seed from clothing, vehicles, animals, or equipment used by tourists, limiting the utility of comparisons between data sets (Pickering \& Mount 2010).

Despite the dearth in research on the subject, it is likely that tourists do have a profound impact on the dispersal of alien seeds. Hikers, for instance, have been shown to carry seeds on their clothing for an average of $13 \mathrm{~km}$, and much further if their travels include a car, aeroplane, train or boat (Ansong \& Pickering 2014a). Protected areas are usually associated with minimal artificial disturbance, reducing the impact of certain other pathways, which highlights the importance of managing this particular pathway of introduction (Pickering \& Mount 2010; Usher et al. 1988).

Tourism and tourism-related activities comprise upwards of $80 \%$ of SANParks' annual revenue, distinguishing it as one of the most successful protected area networks in the world (Biggs et al. 2014). Nonetheless, there are ecological risks associated with an increase in visitor numbers, which highlights the need for environmentally responsible tourism (Cini \& Saayman 2014).

One of the goals of SANParks' strategic adaptive management process is to find a balance between the goals of increased ecotourism and the needs of conservation (Biggs et al. 2014). Achieving this goal will require greater investigation into the role that tourists play in ecosystem processes, and integrating the results of such studies into tourism management (Biggs et al. 2014). A study on the role that tourists play in the dispersal of alien plants presents an opportunity to inform and improve tourism management practices in a way that protects the native flora of South Africa's iconic national parks.

The aim of this study is to investigate the role that three categories of tourists - hikers, dog walkers and cyclists play in alien seed dispersal in a fynbos protected area. By sampling the shoes of visitors, dogs and bicycles for seeds, the role that visitors play in introducing seeds into a protected area is assessed, as well as the types of tourists that act as vectors for seed dispersal. At the same time, vegetation transects at different distances from trails used by these tourists illustrate the distribution of established alien species within the protected area. Since roads have been shown to act as propagules for alien species in protected areas globally (Pauchard \& Alaback 2004), a hypothesis is put forward that greater tourist disturbance closer to trails leads to a greater percentage of cover of alien species in these areas as opposed to areas further into the matrix.

\section{Research method and design Study area}

The Cape Peninsula has a Mediterranean climate, with an average winter rainfall of approximately $2000 \mathrm{~mm}$ per year (Trinder-Smith 2006). Furthermore, the region is characterised by strong gulf winds, blowing primarily southeast to north-west.

The Table Mountain National Park covers $57 \mathrm{~km}^{2}$ and offers over $650 \mathrm{~km}$ of hiking trails (Clarke, Mackensie \& Merry 2013). The Silvermine Nature Reserve section of the Table Mountain National Park, in Cape Town, Western Cape province, South Africa $\left(18^{\circ} 40^{\prime} \mathrm{S}, 34^{\circ} 07^{\prime} \mathrm{E}\right)$, is known for its diverse fynbos vegetation (Figure 1). The soil is very sandy and nutrient poor, with limited phosphorus and nitrogen availability (Trinder-Smith 2006). This section of the park provides various trails for visitors to use, including paths for dog-walking, cycling and hiking. Of the three trails considered in this study, dogs were restricted to the dogwalking trail, as were cyclists to the cycling trail. Hikers, however, could walk on all three trails.

The stretches of the dog-walking and cycling paths investigated in this study were wider than the hiking path. Furthermore, the hiking path utilised in this study was one of the most commonly trafficked trails in the park, which also serves as the start to many other hiking routes.

\section{Interview survey}

Data were collected for 3 days in early February 2015 - the end of the dry season - during peak visiting hours (between 08:00 and 11:00). Whilst it was partly cloudy during the first 2 days of data collection, it rained heavily on the third day, resulting in a decrease in the number of participants and 


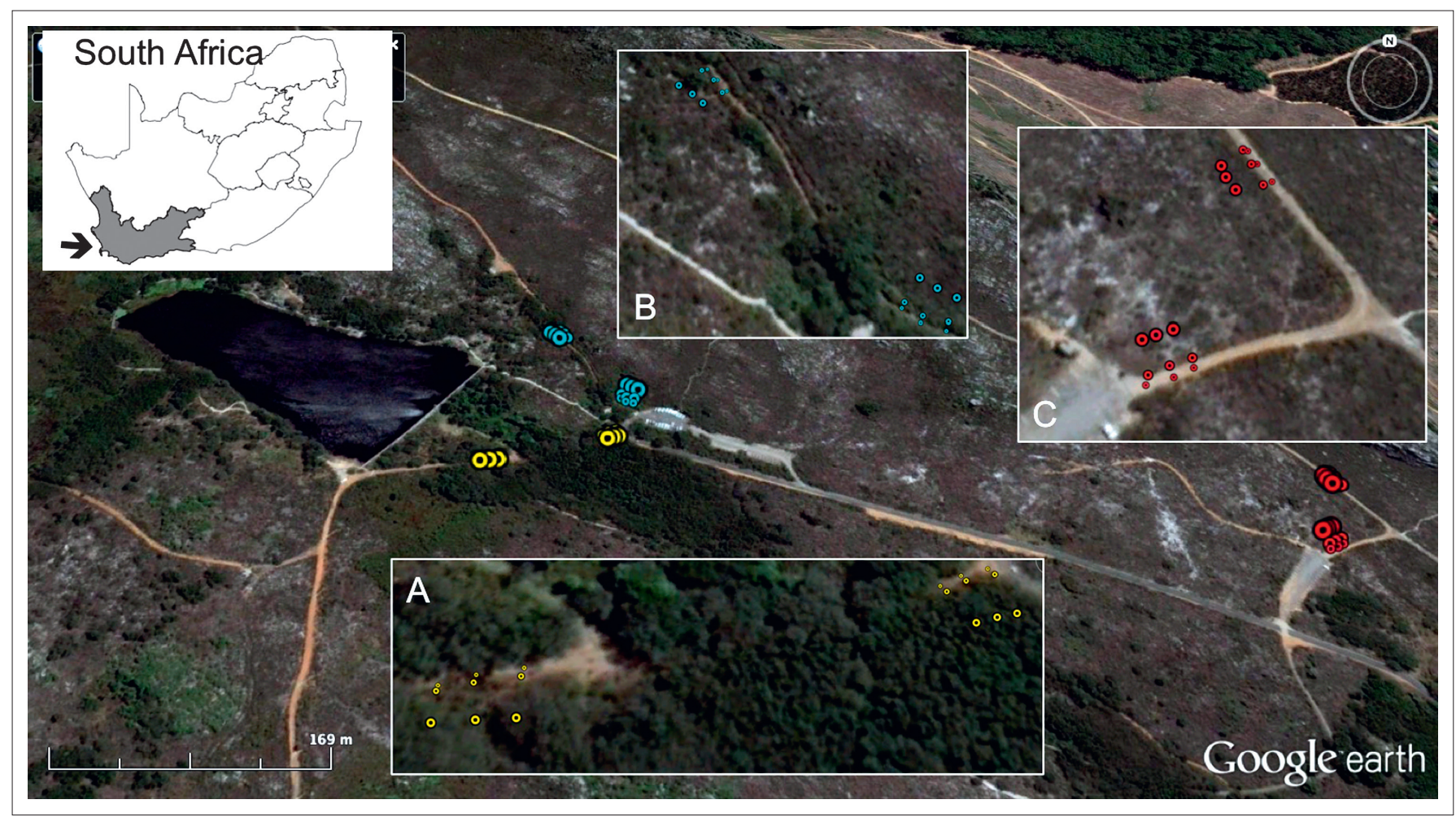

Source: Google Earth

A, dog-walking trail; B, hiking trail; C, cycling trail.

FIGURE 1: Location study area within the Silvermine section of the Table Mountain National Park, Western Cape province, South Africa. The yellow, blue and red rings represent the vegetation transects conducted along the dog-walking, hiking and cycling trails respectively.

overall park traffic on that day. Survey stations were set up at the trailhead of three different paths in Silvermine: a hiking path $\left(18^{\circ} 40^{\prime} \mathrm{S}, 34^{\circ} 08^{\prime} \mathrm{E}\right)$, a cycling path $\left(18^{\circ} 41^{\prime} \mathrm{S}, 34^{\circ} 08^{\prime} \mathrm{E}\right)$ and a dog-walking path $\left(18^{\circ} 40^{\prime} \mathrm{S}, 34^{\circ} 08^{\prime} \mathrm{E}\right)$.

Tourists entering the park were classified into three categories: hikers, dog walkers and cyclists. Each participant was asked a series of questions about their activities (see Appendix 1). The data were further assessed to determine tourists' role in seed dispersal, and the introduction and potential source of alien vegetation into protected areas.

\section{Plant seed collection and categorisation}

At the three survey stations, prior to entering the park, each participant stepped into a $40 \mathrm{~cm} \times 30 \mathrm{~cm}$ plastic container. Here, the soles of shoes were swept, using a long-bristle brush to collect any seeds the individual may have been carrying. The debris was collected into individual plastic bags for later classification. This same procedure was followed to brush off the entirety of the front tyre of each bicycle that was surveyed. The front legs and flank of each dog surveyed was brushed using a dog brush and all the debris collected.

Each debris sample was then examined under an Olympus $\mathrm{CH}$ light microscope (Model LSK [20W], Olympus Corporation of America, New Hyde Park, NY, USA). All of the seeds in these debris samples were counted and categorised by morph. An attempt was made to germinate the seeds in order to identify the species from which each morph had come. However, this was unsuccessful, preventing seed identification beyond the original morph categorisation.

\section{Alien plant survey}

In order to examine the occurrence of alien plants in protected areas, eighteen $10-\mathrm{m}$ transects were set up along recreational trails in Silvermine. Alien species were defined as those that are non-native to South Africa. To compare the potential for different human activities at dispersing alien seeds, three paths were selected: a dog-walking path, a hiking path and a cycling path.

Six transects were set up in two groups on each trail. Using a measuring tape, the first set of 10-m transects was set up $5 \mathrm{~m}$ from the trailhead; the second group of transects, $100 \mathrm{~m}$ from the trailhead (Figure 2). To evaluate the relationship between the percentage of cover of plant species, and distance from the trail, three vegetation transects were conducted: one along the edge of the trail; one $1 \mathrm{~m}$ away; and a third, $10 \mathrm{~m}$ away from the trail (Figure 2).

At each vegetation transect point, a $1 \mathrm{~m}^{2}$ quadrat was used to examine the vegetation cover every $5 \mathrm{~m}$ along each line transect, for a total of three plots. The percentage of cover for all plant species within the quadrats was estimated by identifying the known species to at least genus level and collecting samples that were later identified at a laboratory. 


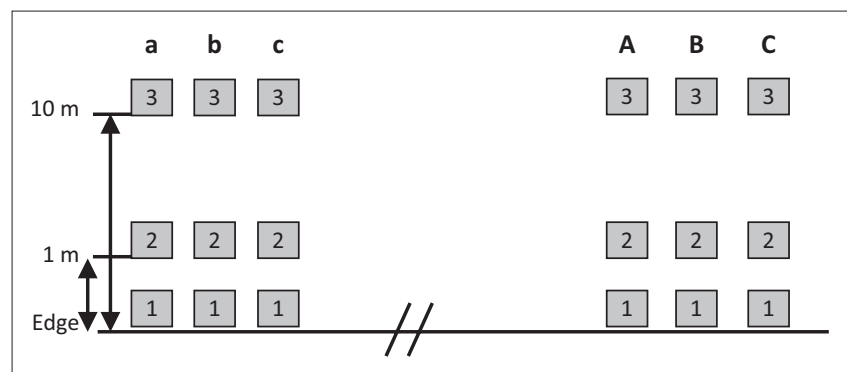

Traihead

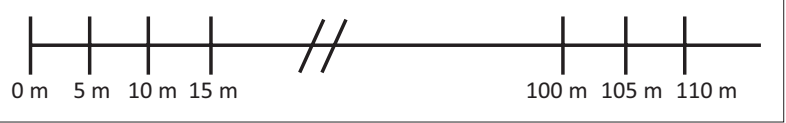

FIGURE 2: Experimental design of vegetation transect survey conducted in the Silvermine section of the Table Mountain National Park in order to investigate the distribution of invasive plants. Three $1-\mathrm{m}^{2}$ quadrats, each represented by a grey square, were sampled along a $10-\mathrm{m}$ line transect. This technique was repeated at $5 \mathrm{~m} \mathrm{(a,b}$ and $\mathrm{c})$ and $100 \mathrm{~m}(\mathrm{~A}, \mathrm{~B}$ and $\mathrm{C})$ from the trailhead. At both of these locations, transects were established at the edge of the trail (1), $1 \mathrm{~m}$ into the matrix (2) and $10 \mathrm{~m}$ into the matrix (3).

To approximate the relative abundances of each plant, the estimated proportion of the plot covered by each particular species was done visually.

To assess the immediacy and severity of the risks posed by the identified alien species, the prioritisation system was used to score each species and to rank them accordingly (Robertson et al. 2003). A prioritisation score was calculated for each species based on an assessment of the impact the species poses in a range of categories. These included long-distance dispersal mechanism, invasive elsewhere, density, biodiversity, impact on water resources, and poison status.

Each category score was first standardised by dividing it by the potential maximum (Robertson et al. 2003). These category scores were summed up and divided by the number of categories, resulting in a weighting score. Species were then ranked according to the product of their total prioritisation score and total confidence interval. A score of 5 represented a species that posed the greatest threat, whilst a score of 0 demarcated no threat.

\section{Data analysis}

To determine the proportion of seeds found per vector, and to account for sampling effort, the number of seeds collected per vector was divided by the sample size of each vector. A PERMANOVA analysis was conducted to analyse the difference between percentage of cover of alien plant species between trail types, distance from the trailhead, and distance into the matrix (PRIMER software version 6.1.5, Clarke \& Gorley 2006).

\section{Results}

\section{Seed survey and collection}

In order to examine their potential as vectors for seed dispersal, a survey and debris collection was conducted among 68 participants entering Silvermine Nature Reserve. Of these 68 participants, 10 were cyclists, 12 were dog walkers (with 19 dogs in total) and 46 were hikers. All of the cyclists and dog walkers lived in the Cape Town area. Of the 46 hikers, 16 were either non-local South Africans, living in Johannesburg or Port Elizabeth, or international visitors from Scotland, England or Germany.

Fifty of the sampled visitors were not carrying any seeds that could be detected. From the remaining 18 participants, a total of 41 seeds and 17 unique seed morphs were isolated (Table 1). It was not possible to identify the seeds to species level, and it therefore remains unknown if these were native or non-native seeds.

Of the participants who were carrying seeds, 16 were from the Cape Town area, one was visiting from England (9 seeds) and one from Germany (1 seed). The English hiker carrying 9 seeds had last worn his shoes in London, and the German hiker had last worn his shoes at Lion's Head, a different part of the Table Mountain National Park. No seeds were found on bicycle tyres, but seeds of two distinct morphs were found on a single cyclist's shoes (Table 1).

When sampling effort and population sample size were taken into account, it was discovered that a larger proportion (75\%) (9 out of 12 that were sampled) of dog walkers carried seeds than any other vector, comprising $42 \%$ of seed morphs (Table 1; Figure 3). Hikers were shown to be the second highest seed disperser type. Of the hikers, 56\% (27 out of 46 that were sampled) carried seeds, representing $19.6 \%$ of the total seed morphs. Only $20 \%$ of the cyclists ( 2 out of 10 that were sampled) carried seeds on their shoes, whilst $15 \%$ of the dogs (3 out of 19 that were sampled) carried seeds (Figure 3).

\section{Vegetation survey}

A total of 54 plots in 18 line transects along the three selected trails in Silvermine were surveyed, and a total of seven invasive plant species were documented (Table 2). The most frequently occurring invasive species were Briza maxima (greater quaking grass, found in 17 quadrats), Lagurus ovatus (hare's tail, found in 7 quadrats) and Stenotaphrum secundatum (coastal buffalo grass, found in 6 quadrats) (Table 2). The dog path had the greatest number of invasive plant species $(n=6)$, whilst the mountain bike path had the fewest invasive plant species $(n=2)$. Furthermore, the dog-walking path had the highest average percentage of cover of invasive species (13.8\%), whilst the hiking path had $9.6 \%$ and the cycling path had only $3.0 \%$ average percentage of cover.

The PERMANOVA analysis demonstrated a significant increase in the percentage of cover of alien plant species in the plots located at the trail edge compared to further into the vegetation matrix (pseudo- $F=3.392, p<0.005, n=18$; Figure 4 ). There was also a significantly higher percentage of cover of alien plants along the dog-walking path than the cycling path (pseudo- $T=2.592, p<0.05, n=12$ ). There was 
TABLE 1: The total number and morph of seeds collected from tourists (cyclists, dog walkers and hikers) entering the Silvermine section of the Table Mountain National Park, and their potential source of origin.

\begin{tabular}{lcll}
\hline $\begin{array}{l}\text { Last place where shoes were } \\
\text { worn/dogs walked }\end{array}$ & $\begin{array}{c}\text { Total number of seeds } \\
\text { per site }\end{array}$ & Mode of dispersal & \multicolumn{1}{c}{$\begin{array}{l}\text { Seed morph and number of seeds } \\
\text { (in parenthesis) }\end{array}$} \\
\hline Silvermine & 10 & MTB shoes & $\begin{array}{l}\text { Total number of } \\
\text { seeds per vector }\end{array}$ \\
& & Dog & $2(1)$ \\
& & Dog walker & $3(1), 4(1)$ \\
$6(1), 8(1)$ & 2 \\
& & Hiker & $12(2), 13(1), 3(1)$ \\
Tokai & 3 & Dog & $5(1)$ \\
& & Dog walker & $9(1), 10(1)$ \\
Kirstenbosch & 2 & Hiker & $14(1), 15(1)$ \\
Lion's Head & 1 & Hiker & $17(1)$ \\
Noordhoek & 1 & Dog walker & $7(1)$ \\
Cape Point & 1 & Hiker & $3(1)$ \\
Masiphumelele & 9 & Hiker & 4 \\
Constantia Nek & 4 & Dog walker & $4(9)$ \\
London & 9 & Hiker & $6(4)$ \\
Lady Slipper, Port Elizabeth & 1 & Hiker & $11(9)$ \\
\hline
\end{tabular}

MTB, mountain bike.

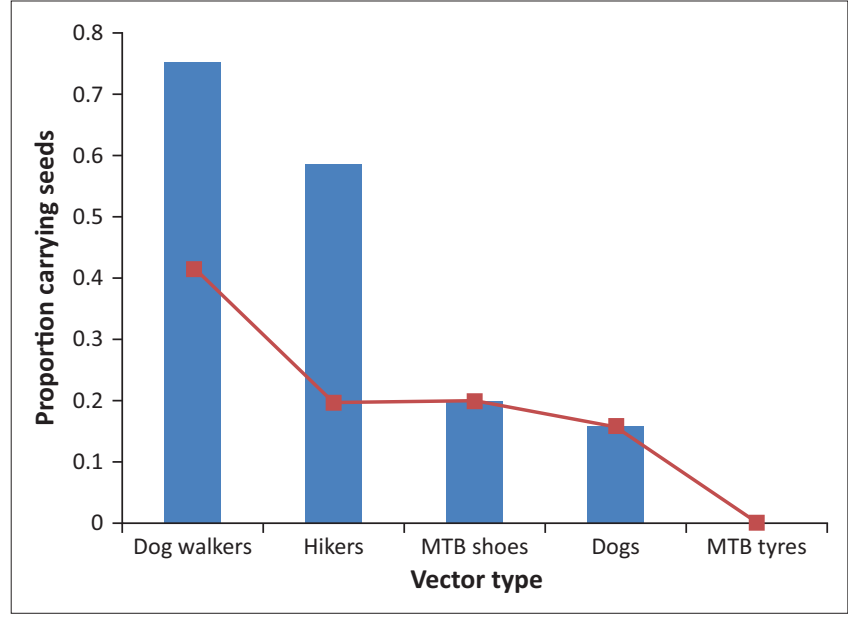

MTB, mountain bike.

FIGURE 3: The proportion of seeds collected from each vector, calculated from the number of seeds divided by vector sample size, to account for sampling effort and population sample size. The black line represents the number of different seed morphs found per vector as a proportion of total seed morphs found.

no significant difference, however, between plots taken $5 \mathrm{~m}$ and $100 \mathrm{~m}$ along the path for all trails.

The highest ranking species with regards to the threatening status of alien species identified in this study obtained a score of 2.74 (giant cane, Arundo donax), whilst the lowest ranking species (L. ovatus) scored 1.56 (Table 3). Species that had high prioritisation and confidence scores, such as A. donax, were of most concern (confidence score $=11.16$; Table 3 ). The high ranking of this species was mainly due to its severe impact on biodiversity (Giessow et al. 2011; Guthrie 2007) and its negative economic impact. This was followed closely by $S$. secundatum (prioritisation score $=2.54$, confidence score $=$ 9.479) and B. maxima (prioritisation score $=2.22$, confidence score $=9.527)($ Table 3$)$.

\section{Discussion}

This study demonstrates that park visitors, in the form of dog walkers, hikers and cyclists, act as seed dispersers in protected areas, corroborating existing research. One study found that humans working in a series of meadows carried seeds from this location on their clothing for an average distance of $13 \mathrm{~km}$ (Auffret \& Cousins 2013). Furthermore, it has been demonstrated that seeds can remain on hikers' shoes for distances as great as $5 \mathrm{~km}$ (Wichmann et al. 2009). The seeds of 16 taxa were found in a single study specifically investigating dispersal via shoes (Clifford 1956). The vehicles considered in studies as a means of seed dispersal, however, have been exclusively motorised, and the only animals investigated have been donkeys and horses (Ansong \& Pickering 2014a; Pickering \& Mount 2010).

The finding that the areas closest to human activity (i.e. near the edge of the trails) are also the areas that are most susceptible to invasion from non-native plants suggests a path-user-mediated mechanism for alien seed dispersal. This evidence is strengthened by a correlation between the relative importance of different potential vectors of seed dispersal and the percentage of cover of alien species on different paths. For instance, dog walkers had the highest incidence of seeds on their shoes; correspondingly, the dog-walking path had the highest percentage of cover of alien plants. Likewise, cyclists carried virtually no seeds, and the cycling trail had the lowest percentage of cover of alien species.

The difference in tendency for different categories of tourists for carrying seeds into the park, therefore, suggests a possible explanation for the differences in the percentage of cover between paths. Whilst the sample sizes used in this study were too small to establish an unambiguous relationship between seed incidence on trail users and the percentage of cover of alien plants along these trails, it is an observation worthy of further investigation. To confirm such a relationship, future studies need to identify the species of collected seeds, particularly since the attempts in this study to propagate and identify seeds were unsuccessful.

Even though the non-native species identified along the sides of the trails are all classified as 'alien', they all play different roles in invading or threatening the environment. In this 
TABLE 2: The percentage of cover of plant species identified to family or genus level, averaged from three 1-metre2 quadrats used in the vegetation transects along the various trails in the Silvermine section of the Table Mountain National Park.

\begin{tabular}{|c|c|c|c|c|}
\hline \multirow[t]{2}{*}{ Metres from trailhead } & \multirow[t]{2}{*}{ Metres away from trail edge } & \multicolumn{3}{|c|}{ Trail type } \\
\hline & & Hiking & Dog-walking & Cycling \\
\hline \multirow[t]{3}{*}{$5 \mathrm{~m}$ from trailhead } & At trail edge $(0 \mathrm{~m})$ & $\begin{array}{l}13 \% \text { Dryopteridaceae } \\
8 \% \text { Asteraceae } A^{\dagger} \\
2 \% \text { Briza maxima } \dagger \\
2 \% \text { Lagurus ovatus } \dagger \\
2 \% \text { Poaceae sp. } \mathrm{B}^{\dagger}\end{array}$ & $\begin{array}{l}77 \% \text { Hemarthria } \mathrm{sp} . \\
2 \% \text { Fingerhuthia africana } \\
2 \% \text { Briza maxima } \dagger \\
13 \% \text { Stenotaphrum secundatum } \dagger\end{array}$ & $\begin{array}{l}77 \% \text { Aizoaceae } \mathrm{A} \\
2 \% \text { Carpobrotus sp. } \\
5 \% \text { Briza maxima }{ }^{\dagger}\end{array}$ \\
\hline & $1 \mathrm{~m}$ away from trail edge & $\begin{array}{l}97 \% \text { Dryopteridaceae } \\
2 \% \text { Ericaceae } \mathrm{A} \\
2 \% \text { Podalyria sp. }\end{array}$ & $\begin{array}{l}8 \% \text { Virgilia } \mathrm{sp} . \\
30 \% \text { Hemarthria } \mathrm{sp} . \\
2 \% \text { Briza maxima } \dagger \\
7 \% \text { Stenotaphrum secundatum } \dagger\end{array}$ & $\begin{array}{l}63 \% \text { Aizoaceae B } \\
2 \% \text { Unknown } \\
7 \% \text { Briza maxima } \dagger\end{array}$ \\
\hline & $10 \mathrm{~m}$ away from trail edge & $\begin{array}{l}7 \% \text { Carpobrotus sp. } \\
2 \% \text { Metalasia sp. } \\
2 \% \text { Dryopteridaceae } \\
52 \% \text { Ericaeae A } \\
30 \% \text { Cliffortia sp. }\end{array}$ & $0.3 \%$ Asteraceae $\mathrm{A} \dagger$ & $\begin{array}{l}3 \% \text { Aizoaceae A } \\
7 \% \text { Stoebe sp. } \\
18 \% \text { Hemarthria sp. } \\
3 \% \text { Hyparrhenia sp. } \\
8 \% \text { Restio sp. A } \\
3 \% \text { Briza maxima } \dagger \\
\text { 2\% Lagurus ovatus } \dagger\end{array}$ \\
\hline \multirow[t]{3}{*}{$100 \mathrm{~m}$ from trailhead } & At trail edge $(0 \mathrm{~m})$ & $\begin{array}{l}\text { 10\% Aizoaceae } \mathrm{A} \\
0.3 \% \text { Osteopermum sp. } \\
3 \% \text { Sporobolus sp. } \\
0.3 \% \text { Struthiola sp. } \\
0.3 \% \text { Unknown } \\
0.3 \% \text { Arundo donax } \dagger \\
2 \% \text { Asteraceae } A \dagger \\
18 \% \text { Briza maxima } \dagger \\
11 \% \text { Lagurus ovatus } \dagger\end{array}$ & $\begin{array}{l}2 \% \text { Aizoaceae } \mathrm{A} \\
37 \% \text { Hyparrhenia } \mathrm{sp} . \\
0.3 \% \text { Cliffortia } \mathrm{sp} . \\
4 \% \text { Plantaginaceae } \dagger \\
18 \% \text { Briza maxima } \dagger \\
0.3 \% \text { Stenotaphrum secundatum } \dagger\end{array}$ & $\begin{array}{l}2 \% \text { Senecio sp. } \\
2 \% \text { Ericaceae A } \\
2 \% \text { Ericaceae C } \\
2 \% \text { Ericaceae } \mathrm{E} \\
23 \% \text { Restio sp. } \mathrm{B} \\
5 \% \text { Phylica } \mathrm{sp} . \\
5 \% \text { Unknown } \\
3 \% \text { Cliffortia sp. } \\
0.3 \% \text { Briza maxima } \dagger \\
0.3 \% \text { Lagurus ovatus } \dagger\end{array}$ \\
\hline & $1 \mathrm{~m}$ away from trail edge & $\begin{array}{l}10 \% \text { Ericaceae } \mathrm{A} \\
0.3 \% \text { Virgilia } \mathrm{sp} . \\
2 \% \text { Sporobolus } \mathrm{sp} . \\
66 \% \text { Cliffortia } \mathrm{sp} . \\
10 \% \text { Briza maxima }\end{array}$ & $\begin{array}{l}3 \% \text { Aizoaceae } \mathrm{A} \\
23 \% \text { Hyparrhenia sp. } \\
33 \% \text { Briza maxima } \\
2 \% \text { Lagurus ovatus }\end{array}$ & $\begin{array}{l}15 \% \text { Ericaceae } \mathrm{A} \\
5 \% \text { Ericaeae C } \\
10 \% \text { Restio } \mathrm{sp} . \mathrm{B} \\
13 \% \text { Phylica } \mathrm{sp} . \\
12 \% \text { Cliffortia } \mathrm{sp} .\end{array}$ \\
\hline & $10 \mathrm{~m}$ away from trail edge & $\begin{array}{l}28 \% \text { Ericaeae } \mathrm{A} \\
8 \% \text { Podalyria } \mathrm{sp} . \\
43 \% \text { Cliffortia } \mathrm{sp} .\end{array}$ & $\begin{array}{l}37 \% \text { Dryopteridaceae } \\
27 \% \text { Ericaceae } \mathrm{A} \\
7 \% \text { Podalyria sp. }\end{array}$ & $\begin{array}{l}25 \% \text { Ericaceae A } \\
27 \% \text { Ericaceae B } \\
5 \% \text { Ericaceae D } \\
15 \% \text { Restio sp. B } \\
5 \% \text { Cliffortia sp. }\end{array}$ \\
\hline
\end{tabular}

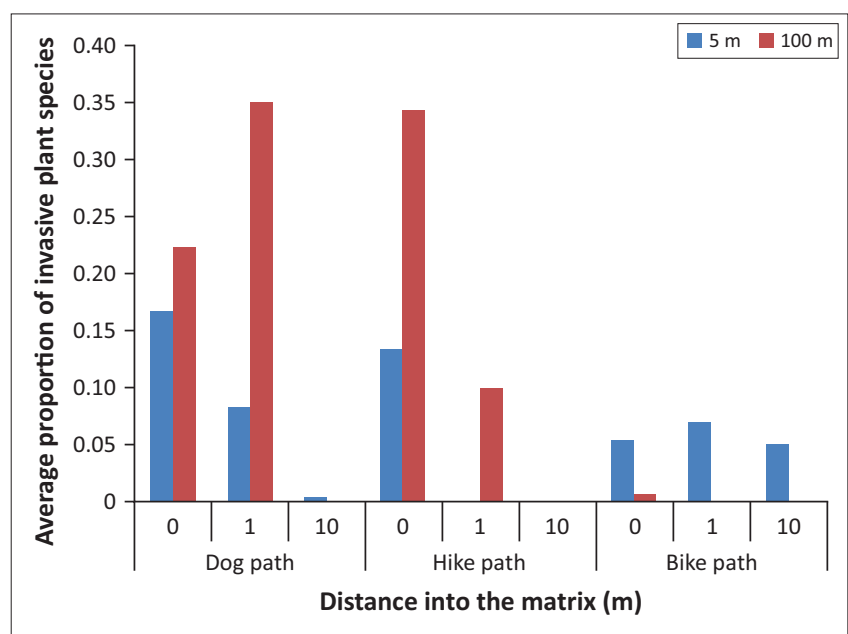

FIGURE 4: The average proportional cover of alien plant species along three different paths in the Silvermine section of the Table Mountain National Park, taken at $0 \mathrm{~m}, 1 \mathrm{~m}$ and $10 \mathrm{~m}$ into the matrix and measured at $5 \mathrm{~m}$ and $100 \mathrm{~m}$ from the trailhead.

study, the alien cane species $A$. donax represented the largest alien risk compared to the other species, which was also found by Robertson et al. (2003) where this species received a total prioritisation score of 3.08 .

Arundo donax, a tall perennial cane native to eastern Asia, has been introduced into many areas for erosion control (Mariani et al. 2010). However, it has a tendency to outcompete native plant species, reduce wildlife habitat and modify river hydrology (Giessow et al. 2011). Invasion by A. donax alters biomass, thereby increasing the fuel load and creating a potential fire hazard (Guthrie 2007). Even though this species only covered a small area in the hiking trail $100 \mathrm{~m}$ away from the trailhead, a monitoring programme is needed to prevent further invasion. This species may easily spread to other areas since reproduction occurs almost entirely from rhizomes and stem fragments (Boose \& Holt 1999).

Significantly, a number of the invasive species that were found along the paths' edge are used in Southern Africa for decorative purposes, including B. maxima and L. ovatus (Van Oudtshoorn 2002). Furthermore, Pauchard and Alaback (2004) found that the land-use type surrounding protected areas influences the numbers and types of plants that are able to invade protected areas. The highly developed landscape surrounding Silvermine is likely rich in decorative plants, considering the large anthropocentric role in determining the ecological makeup of urban areas (Aronson et al. 2014).

Together, these findings suggest that tourists are possibly dispersing seeds from their gardens, a source of alien species now recognised as one of the most challenging to combat (Mack 2003; Mack \& Lonsdale 2001). The spread of ornamental grasses such as B. maximus and L. ovatus has been attracting greater attention in South Africa (Milton 2004), and researchers have begun to investigate the threat posed to South African protected areas by ornamental plant species (Foxcroft, Richardson \& Wilson 2008). It seems likely that this same mechanism is operating in Silvermine. 
TABLE 3: The prioritisation scores of alien plants species surveyed on the trails in the Silvermine section of the Table Mountain National Park. The scores were calculated using the alien species prioritisation system.

\begin{tabular}{llcc}
\hline Rank & Alien plant species & Prioritisation score & Confidence score \\
\hline 1 & Arundo donax & 2.744 & 4.067 \\
2 & Briza maxima & 2.222 & 3.933 \\
3 & Stenotaphrum secundatum & 2.539 & 3.733 \\
4 & Lagurus ovatus & 1.567 & 9.527 \\
\hline
\end{tabular}

Source: Robertson, M.P., Villet, M.H., Fairbanks, D.H.K., Henderson, L., Higgins, S.I., Hoffmann, J.H. et al., 2003, 'A proposed prioritization system for the management of invasive alien plants in South Africa', South African Journal of Science 99, 37-43

Priorities for future studies should include more comprehensive seed collection techniques. Through the course of this study, it was observed that more seeds appeared to become caught on the socks of researchers rather than on the shoes. This observation suggests that clothing other than shoes could be important mechanisms for dispersal.

The socks of participants were not a priority in this study because socks are typically washed between each use. It was therefore less likely that more seeds could be brought into Silvermine on socks than on shoes, which was the primary focus of this study. Socks may play a more important role in dispersing seeds within protected areas than in introducing seeds into those protected areas. In addition, car tyres represent a potential vector for invasive seeds that remains unexamined in the context of South African protected areas. Future studies should take this into account when considering the method of seed collection - it is suggested that the clothes and vehicles of participants are sampled in addition to shoes.

To limit the spread of non-native plant species into pristine ecosystems, protected area managers must take an active role in monitoring tourists in accordance with the SANParks Biodiversity Management Programme for Invasive Alien Species (McGeoch et al. 2011).

Tourism is the main source of revenue for South African protected areas, and a major goal for SANParks is to encourage ecotourism that does not compromise the agency's commitment to conservation (Biggs et al. 2014).

Some research on the means of minimising tourist-mediated seed dispersal has already been conducted in other countries. A study by Ansong and Pickering (2014b) found that the vast majority of tourists entering an Australian protected area were aware of the potential capacity for unintentionally dispersing invasive plant seeds.

Over half of the individuals surveyed by Ansong and Pickering (2014b) supported greater funding toward nonnative species removal, and a vast majority of respondents either supported or felt neutral towards an initiative requiring tourists to remove seeds from their clothing and equipment before entering the park (Ansong \& Pickering 2014b). These results indicate that an educational campaign about seed dispersal by tourists could have widespread public support (Ansong \& Pickering 2014b). Primarily, these efforts should focus on the correct form of disposal for seeds attached to clothing, shoes, dogs or recreational equipment, since many tourists interviewed said they threw seeds away indiscriminately (Ansong \& Pickering 2014b).

Information posters at trail heads about the dangers of alien species and the correct method for the removal of seeds could be one easy method of raising awareness and decreasing the incidence of unintentional dispersal. Shoe-sweeping stations in trailhead parking lots could similarly provide a costeffective and convenient method for tourists to remove seeds from their shoes. The implementation of such measures could help to prevent the further spread of non-native plants species into Silvermine Nature Reserve, and elsewhere in South Africa's national parks.

\section{Conclusion}

This research adds to the small body of existing evidence concerning the spread of invasive seeds by tourists. Tourist surveys and vegetation transects conducted in the Silvermine Nature Reserve section of the Table Mountain National Park demonstrate a clear link between tourist disturbance measured as distance from the path into the matrix - and percentage of cover of invasive plants. At the same time, the path used by dog walkers, who were found to have the highest load of seeds, have the highest overall percentage of cover of invasive species. These results demonstrate that tourists can act as vectors for invasive alien species dispersal, highlighting the need for active tourism management in line with SANParks' Biodiversity Monitoring Programme.

\section{Acknowledgments}

The authors would like to thank Dr Laurence Kruger for his assistance in plant identification. They would also like to thank the Organisation for Tropical Studies and SANParks for their roles in facilitating this project.

\section{Competing interests}

The authors declare that they have no financial or personal relationships, which may have inappropriately influenced them in writing this article.

\section{Authors' contributions}

K.M. (Organisation for Tropical Studies) was the project leader and responsible for project design. E.H.B. (Wheaton College), L.E.L. (Washington University), C.M.L.M. (Grinnell College), S.M.R. (Yale University) and E.M.V. (Bowdoin College) were responsible or conducting the fieldwork and the analyses of data. 


\section{References}

Ansong, M. \& Pickering, C., 2014a, 'Weed seeds on clothing: A global review', Journal of Environmental Management 144, 203-211. PMID: 24956465, http://dx.doi. org/10.1016/j.jenvman.2014.05.026

Ansong, M. \& Pickering, C., 2014b, 'Weed hygiene: What do we do with seeds we find on our clothing?', Nineteenth Australasian Weeds Conference, pp. 42-45.

Aronson, M.F., La Sorte, F.A., Nilon, C.H., Katti, M., Goddard, M.A., Lepczyk, C.A. et al. 2014, 'A global analysis of the impacts of urbanization on bird and plant diversity reveals key anthropocentric drivers', Proceedings of the Royal Society B: Biological Sciences 281(1780), 20133330. PMID: 24523278, http://dx.doi.org/10.1098/ rspb.2013.3330

Auffret, A.G. \& Cousins, S.A.O., 2013, 'Humans as long-distance dispersers of rura plant communities', PLoS One 8(5), e62763. PMID: 23658770, http://dx.doi. org/10.1371/journal. pone.0062763

Biggs, D., Swemmer, L., Phillips, G., Stevens, J., Freitag, S. \& Grant, R., 2014, 'The development of a tourism research framework by South African National Parks to inform management', Koedoe 56(2), Art. \#1164, 9 pages. http://dx.doi. org/10.4102/koedoe.v56i2.1164

Boose, A.B. \& Holt, J.S., 1999, 'Environmental effects on asexual reproduction in Arundo donax', Weed Research 39, 117-127. http://dx.doi.org/10.1046/j.13653180.1999.00129.x

Cini, F. \& Saayman, M., 2014, 'Which age group spends the most in a national park?', Koedoe 56(2), Art. \#1158, 8 pages. http://dx.doi.org/10.4102/koedoe.v56i2.1158

Clarke, K.R. \& Gorley, R.N., 2006, Primer version 6.1.5 User Manual/Tutorial, Plymouth, Primer-E Ltd, UK.

Clarke, H., Mackensie, B. \& Merry, C., 2013, Common wild flowers of table mountain \& silvermine, Struik Nature, Cape Town.

Clifford, H.T., 1956, 'Seed dispersal on footwear', Proceedings of the Botanical Society of the British Isles 2, 129-131.

Forest, F., Grenyer, R., Rouget, M., Davies, T.J., Cowling, R.M., Faith, D.P. et al., 2007 'Preserving the evolutionary potential of floras in biodiversity hotspots', Nature 445, 757-760. PMID: 17301791, http://dx.doi.org/10.1038/nature05587

Foxcroft, L.C., 2009, 'Developing thresholds for potential concern for invasive alien species: Hypotheses and concepts', Koedoe 50(1), Art. \#157, 6 pages. http:// species: Hypotheses and concepts',
dx.doi.org/10.4102/koedoe.v51i1.157

Foxcroft, L.C., Richardson, D.M. \& Wilson, J.R., 2008, 'Ornamental plants as invasive aliens: Problems and solutions in Kruger National Park, South Africa', Environmental Management 41(1), 32-51. PMID: 17943344, http://dx doi. org/10.1007/s00267-007-9027-9

Giessow, J., Casanova, J., Leclerc, R., MacArthur, R., Fleming, G. \& Giessow, J., (Else) 2011, Arundo donax (giant reed): Distribution and Impact Report, Agreement No. 06-374-559-0, State Water Resources Control Board, California Plant Council (Cal-IPC).

Guthrie, G., 2007, 'Impacts of the invasive reed Arundo donax on biodiversity at the community-ecosystem level', MSc thesis, Biodiversity and Conservation Biology Department, University of Cape Town, Cape Town

Mack, R.N., 2003, 'Global plant dispersal, naturalization, and invasion: Pathways, modes, and circumstances', in J. Carlton (ed.), Invasive species: Vectors and management solutions, pp. 3-30, Island Press, Washington, DC.

Mack, R.N. \& Lonsdale, W.M., 2001, ‘Humans as Global Plant Dispersers: Getting More Than We Bargained For: Current introductions of species for aesthetic purposes present the largest single challenge for predicting which plant immigrants will
become future pests', BioScience 51(2), 95-102. http://dx.doi.org/10.1641/0006become future pests', BioScience 51(2),
3568(2001)051[0095: hagpdg]2.0.co;2
Mariani, C., Cabrini, R., Danin, A., Piffanelli, P., Fricano, A., Gomarasca, S. et al., 2010, 'Origin, diffusion and reproduction of the giant reed (Arundo donax L.): A promising weedy energy crop', Annals of Applied Biology 157, 191-202. http:// dx.doi.org/10.1111/j.1744-7348.2010.00419.x

McGeoch, M.A., Dopolo, M., Novellie, P., Hendriks, H., Freitag, S., Ferreira, S. et al., 2011, 'A strategic framework for biodiversity monitoring in South African National Parks', Koedoe 53(2), Art. \#991, 10 pages. http://dx.doi.org/10.4102/koedoe. v53i2.991

Milton, S.J., 2004, 'Grasses as invasive alien plants in South Africa', South African Journal of Science 100(1/2), 69-75. https://www.dwa.gov.za/wfw/docs/ Milton,2004.pdf

Myers, N., Mittermeier, R.A., Mittermeier, C.G., Da Fonseca, G.A.B. \& Kent, J., 2000 'Biodiversity hotspots for conservation priorities', Nature 403, 853-858. PMID: 10706275, http://dx.doi.org/10.1038/35002501

Pauchard, A. \& Alaback, P.B., 2004, 'Influence of elevation, land use, and landscape context on patterns of alien plant invasions along roadsides in protected areas of south-central Chile', Conservation Biology 18, 238-248. http://dx.doi. org/10.1111/j.1523-1739.2004.00300.x

Pickering, C. \& Mount, A., 2010, 'Do tourists disperse weed seed? A global review of unintentional human-mediated terrestrial seed dispersal on clothing, vehicles and horses', Journal of Sustainable Tourism 18(2), 239-256. http://dx.doi. org/10.1080/09669580903406613

Pickering, C., Mount, A., Wichmann, M.C. \& Bullock, J.M., 2011, 'Estimating humanmediated dispersal of seeds within an Australian protected area', Biological Invasions 13(8), 1869-1880. http://dx.doi.org/10.1007/s10530-011-0006-y

Richardson, D.M. \& Van Wilgen, B.W., 2004, 'Invasive alien plants in South Africa: How well do we understand the ecological impacts?', South African Journal of Science 100(1/2), 45-52. http://dx.doi.org/10.1007/s10021-012-9605-4

Robertson, M.P., Villet, M.H., Fairbanks, D.H.K., Henderson, L., Higgins, S.I., Hoffmann, J.H. et al., 2003, 'A proposed prioritization system for the management of invasive alien plants in South Africa', South African Journal of Science 99, 37-43.

Swearingen, J., Reshetiloff, K., Slattery, B. \& Zwicker, S., 2010, Plant invaders of midAtlantic natural areas, National Park Service and U.S. Fish \& Wildlife Service, Washington, DC

Trinder-Smith, T., 2006, Wild flowers of the table mountain national park: South African wild flower guide 12, Botanical Society of South Africa, Cape Town.

Usher, M.B., 1988, 'Biological invasions of nature reserves: A search for generalizations', Biological Conservation 44, 119-135. http://dx.doi.org/10.1016/0006-3207(88) 90007-9

Usher, M.B., Kruger, F.J., Macdonald, I.A.W., Loope, L.L. \& Brockie, R.E., 1988, 'The ecology of biological invasions into nature reserves: An introduction', Biological Conservation 44, 1-8. http://dx.doi.org/10.1016/0006-3207(88)90002-X

Van Oudshoorn, F., 2002, Guide to Grasses of southern Africa, Briza Publications, Pretoria.

Wichmann, M.C., Alexander, M.J., Soons, M.B., Galsworthy, S., Dunne, L., Gould, R. et al., 2009, 'Human-mediated dispersal of seeds over long distances', Proceedings of the Royal Society B: Biological Sciences 276, 523-532. PMID: 18826932, http:// dx.doi.org/10.1098/rspb.2008.1131

Wilson, J.R.U., Gairifo, C., Gibson, M.R., Arianoutsou, M., Bakar, B.B., Baret, S. et al ., 2011, 'Risk assessment, eradication, and biological control: Global efforts to 2011, 'Risk assessment, eradication, and biological control: Global efforts to
limit Australian acacia invasions', Diversity Distribution 17(5), 1030-1046. http:// limit Australian acacia invasions', Diversity Dist
dx.doi.org/10.1111/j.1472-4642.2011.00815.x

Wilson, J.R.U. Ivey, P. Manyama, P., Nänni, I, 2013, 'A new national unit for invasive species detection, assessment and eradication planning', South African Journal of Science 109(5/6), Art. \#0111, 13 pages. http://dx.doi.org/10.1590/ sajs.2013/20120111 


\section{Appendix 1}

Interview questionnaire presented to participants at the entrance of visitor trails in the Silvermine section of the Table Mountain National Park

1. Where are you from?

2. What are you doing?

1. Cycling

2. Walking/hiking/dog-walking

3. Where did you last:

1. Wear your shoes?

2. Ride your bike?

3. Walk your dog? 